\title{
Memahami Komunikasi Antarpribadi Dalam Perkawinan Campuran Pasangan Suami Istri Beda Negara Indonesia - Italia
}

\author{
Ari Murti Ani \\ (Arimuti@yahoo.com) \\ Alumni Ilmu Komunikasi FTIK USM
}

\begin{abstract}
The paper aims to understand and describe the understanding of interpersonal communication is done by married couples of different countries in the intermarriage. The theoretical basis of this research is interactionism symbolic by George Herbert mead (1934) describes the thinking is the interaction that occurs in an individual, how language is essential for the formation of human characteristics which consist of Mind, Self and Society. The process of symbolic form of messages and symbols. Based on research that has been done, it can be concluded that the verbal and nonverbal communication is a form of symbolic interaction that happens to couples from different countries and the adjustment effort in communicating basically used by mutual consent.
\end{abstract}

Kata Kunci: Komunikasi Interpersonal , Verbal , Non Verbal , Simbol

\section{Pendahuluan}

Perkawinan dengan perbedaan kewarganegaraan (Campuran) bukanlah hal yang asing lagi saat ini terutama dengan keadaan dan perkembangan masyarakat. Banyaknya perkawinan beda negara memang tengah marak di kalangan masyarakat. Perbedaan yang paling mendasar adalah perbedaan budaya. Perilaku yang berbeda pada tiap individu menjadi salah satu faktor yang menghambat dalam suatu proses penyampaian pesan. Komunikasi antarbudaya merupakan salah satu bentuk komunikasi yang di lakukan oleh dua orang atau lebih pribadi yang kebudayaannya berbeda (Liliweri, 2004: 136).

\footnotetext{
Dalam Moediarti (2009: 78), perkawinan campuran dapat dilaksanakan di Indonesia ataupun di luar Indonesia dan hukumnya sah. Sebagaimana diatur dalam UndangUndang No. 1 Tahun 1974 pasal 56 ayat 1 tentang perkawinan yang berbunyi:
}

\begin{abstract}
"Perkawinan di Indonesia antara dua orang warganegara Indonesia atau seorang warganegara Indonesia dengan warga negara Asing adalah sah bilamana dilakukan menurut hukum yang berlaku di negara dimana perkawinan itu dilangsungkan dan bagi warganegara Indonesia tidak melanggar ketentuan Undang-undang ini"”.
\end{abstract}

Komunikasi antarpribadi adalah proses dimana orang menciptakan dan mengelola hubungan, melaksanakan tanggung jawab secara timbal balik dalam menciptakan makna (Budyatna dan Mona, 2011:14). Perkawinan campuran sering menimbulkan kesulitan-kesulitan seperti konflik antar pasangan dibandingkan perkawinan biasa atau dalam budaya yang sama. Berdasarkan konflik yang terjadi pada pasangan suami istri beda negara ini komunikasi adalah media yang dapat menciptakan atau mengatur konflik. Melalui komunikasi inilah, kita dapat 
membuat hubungan kita dengan pasangan menjadi konstruktif atau destruktif. Peneliti melakukan penelitian terhadap pasangan suami istri beda negara dan mengambil dua pasangan suami istri sebagai informan. Penelitian ini meneliti subjek penelitian yaitu pasangan beda negara Indonesia - Italia yang mempunyai cara yang khas dan tersendiri dalam berkomunikasi dan pasangan Indonesia - Jerman sebagai pasangan pembanding.

\section{Tinjauan Pustaka}

Interaksi simbolik adalah salah satu teori yang diakui Mulyana (2002: 70) menyarankan bahwa perilaku seseorang itu sewajarnya dipelajari sebagai proses yang membentuk dan mengatur perilakunya sendiri sekaligus mempertimbangkan harapan-harapan orang lain yang menjadi mitra interaksi mereka. Teori interaksi simbolik dikembangkan oleh George Herbert Mead (1934). Teori ini menjelaskan tentang pemikiran George Herbert Mead adalah interaksi yang terjadi dalam individu, bagaimana bahasa penting bagi pembentukan karakteristik manusia yang terdiri dari Mind (pikiran), Self (diri)dan Society (masyarakat). Penyebaran dan pengembangan teori mead di populerkan oleh Herbert Blumer dan menciptakan istilah "Interaksi Simbolik" pada tahun 1937.

Mind (Pikiran) adalah sebuah proses, berpikir melalui situasi dan merencakan sebuah tindakan terhadap objek melalui pemikiran simbolik. Mind atau pikiran, menurut Mead muncul bersamaan dengan proses komunikasi yang melibatkan bahasa serta gerak tubuh. Pikiran muncul dan berkembang dalam proses sosial dan merupakan bagian dari proses sosial (Griffin, 2012: 58).

Self (Diri) adalah fungsi dari bahasa karena dapat merespon kepada diri sendiri sebagai objek. The Self atau diri, menurut Mead merupakan ciri khas dari manusia. Diri adalah kemampuan untuk menerima diri sendiri sebagai sebuah objek dari perspektif yang berasal dari orang lain, atau masyarakat. Diri muncul dan berkembang melalui aktivitas interaksi sosial dan bahasa juga memungkinkan orang berperan dalam percakapan dengan orang lain karena adanya simbol (Griffin, 2012: 59-60).

Society, masyarakat hanya dipandang secara umum sebagai proses sosial yang mendahului Mind (pikiran) dan Self (diri). Tetapi yang terpenting bahwa di setiap diri individu di dalamnya juga terdapat orang lain, dan terjadi interaksi (Griffin, 2012: 60-61).

Proses simbolik yang dimaksud adalah seorang komunikator dalam menyampaikan suatu pesan kepada komunikan menggunakan 2 faktor yaitu pesan dan lambang. Isi pesan pada umumnya adalah pikiran dan lambang pada umumnya adalah Bahasa (verbal). Lambang atau simbol tersebut sebagai media atau saluran dalam berkomunikasi dan dapat berupa gerak tubuh/gesture (nonverbal) yang mengacu pada setiap tindakan yang memiliki makna (Marhaeni, 2009:3436).

Interaksi simbolik menurut Mulyana (2002: 68) adalah suatu aktivitas yang merupakan ciri khas manusia yakni komunikasi atau pertukaran simbol yang diberi makna khusus dan menimbulkan interpretasi atau penafsiran. Simbolik berasal dari 
kata "symbol" yakni tanda yang muncul dari hasil kesepakatan bersama. Di dalam interaksionisme simbolik, seseorang memberikan informasi hasil dari pemaknaan simbol dari perspektifnya kepada orang lain dan orang penerima informasi tersebut akan memiliki perspektif lain dalam memaknai informasi yang disampaikan melalui proses saling mempengaruhi sebuah tindakan sosial yang akan mengeluarkan bahasa-bahasa, kebiasaan atau simbol-simbol baru.

Budaya terdiri dari bahasa dan perilaku yang terjadi di dalam bentukbentuk kegiatan serta tindakan penyesuaian diri dalam berkomunikasi karena budaya dan komunikasi tidak dapat dipisahkan. Sementara itu, bahasa merupakan simbol yang memungkinkan orang berbagi makna (Hardjana, 2003: 23). Tanpa bahasa akan terjadi kekurangan kemampuan dalam berbahasa sehingga sangat sulit terciptanya komunikasi.

Beulah Rohrlich (Dodd, 1998: 71) menyatakan, bahwa dalam keluarga perkawinan campuran, komunikasi merupakan hal utama yang sering muncul. Karena itu, Rohrlich memberikan beberapa alternatif dalam upaya penyesuaian:

a. Penyesuaian satu arah (one way adjustment).

b. Penyesuaian alternatif (alternative adjustment

c. Kompromi midpoin (midpoint compromised).

d. Penyesuaian campuran (mixing adjustment).

e. Penyesuaian kreatif (creative adjustment).

Pembahasan
Dalam perkawinan campuran kebutuhan berbagi satu sama lain menjadi suatu cara untuk tetap dapat menciptakan suatu bentuk komunikasi agar hubungan yang terjalin harmonis, dan masing-masing pasangan memiliki keinginan yang sama untuk dapat mengembangkan kemampuan berkomunikasi satu sama lain. Perkawinan campuran mengalami proses adaptasi dalam penyesuaian keseimbangan ketika berkomunikasi, seperti halnya komunikasi verbal dan nonverbal.

\section{a. Komunikasi Verbal}

Dalam komunikasi verbal, bahasa memegang peranan penting karena bahasa adalah salah satu cara terbaik dalam menggambarkan keadaan apapun. Berbagai bahasa mempunyai aksen dan dialek yang berbeda tiap negara. Pada temuan penelitian terhadap pasangan Indonesia - Italia, Peneliti menemukan cara berkomunikasi yang baru dan berbeda dalam hal bahasa. Mereka membuat cara bahasa sendiri yang disebut dengan Bahasa Mix. Bahasa Mix karena didalam satu kalimat bisa memasukan 5 bahasa sekaligus yaitu Indonesia, Italia, Roma, Inggris dan Jawa. Mereka menciptakan Bahasa mix setelah mereka menikah untuk berkomunikasi secara nyaman, mudah dimengerti dan mencoba sesuatu yang berbeda. Bahasa mix yang dimaksud adalah campuran beberapa bahasa dalam satu kalimat. Bahasa mix merupakan ciri khas dari pasangan Indonesia- Italia ini, awal mula mereka memakai bahasa campur aduk karena keterbatasan masing-masing individu dalam memahami sebuah bahasa sehingga kebiasaan- kebiasaan ini menjadi berlanjut dan menciptakan cara komunikasi yang baru dengan simbol bahasa mix. Bahasa merupakan simbol 
yang memungkinkan orang berbagi, orang harus memahami komunikasi seperti isyarat-isyarat halus yang implisit dalam bahasa, nada suara, gerak gerik dan ekspresi sering berbeda secara kultural (Mulyana dan Rakhmat, 2009: 58).

Bahasa sebagai simbol yang dipilih oleh pasangan suami istri Indonesia - Jerman adalah Bahasa Indonesia dan Bahasa inggris. Seperti pasangan perkawinan campuran pada umumnya kedua bahasa ini adalah bahasa umum yang digunakan semua pasangan dengan latar belakang budaya yang berbeda tetapi karena minimnya bahasa yang mereka kuasai tak pelak sering membuat kesalahpahaman yang terjadi dalam masa perkawinan karena cara berkomunikasi mereka tidak mempunyai symbol khusus yang mereka ciptakan untuk mempermudah komunikasi.

\section{b. Komunikasi Nonverbal}

Dari hasil pengamatan Peneliti menemukan beberapa simbol nonverbal yang sering digunakan pada pasangan Indonesia - Itali dengan menggunakan gerak isyarat tangan dan jari, bahasa tubuh, ekspresi wajah dan kontak mata dan sebagainya. Beberapa simbol dengan menggunakan jari tangan mereka gunakan dalam berkomunikasi sebagai bentuk simbol dan petunjuk dalam berkomunikasi. Ada simbol yang memang menjadi bagian dari simbol orang-orang italia tetapi mereka kembangkan sendiri sehingga menjadi simbol yang khas.

Simbol - simbol yang terjadi dalam kehidupan nyata komunikasi nonverbal jauh lebih banyak dipakai daripada komunikasi verbal. Simbolsimbol terjadi untuk mendapatkan kesan, gaya emosi, dan gaya berbicara.
Karena itu, komunikasi nonverbal bersifat tetap dan selalu ada. Komunikasi nonverbal lebih jujur mengungkapkan hal yang mau diungkapkan karena spontan (Budyatna dan Mona, 2011: 110-115).

Komunikasi merupakan faktor terpenting dalam penyesuaian perkawinan campuran. Komunikasi antarpribadi dapat berbentuk verbal dan nonverbal dimana pelaku komunikasi mentransfer dan mengelola suatu pesan secara lengkap jelas dan benar dan kesalahpahaman. Apa yang terjadi adalah sebuah fenomena kehidupan khususnya kehidupan rumah tangga dalam perkawinan campuran, dimana pasangan suami istri berbeda negara dituntut untuk sebuah proses komunikasi yang berbeda yang tidak seperti pasangan suami istri pada umumnya yang memiliki latar belakang kebudayaan yang sama.

Pada pasangan suami istri Indonesia - Jerman yang peneliti teliti tidak menciptakan simbol secara khusus seperti pasangan sebelumnya, mereka juga tidak menggunakan simbol sama sekali karena mereka menginginkan cara yang lebih mudah hanya dengan menggunakan komunikasi verbal.

Perkawinan campuran harus memiliki komunikasi ekstra daripada pasangan suami istri lain pada umumnya, karena komunikasi verbal dan nonverbal adalah sebuah interaksi karena perbedaan latar belakang budaya sehingga didalam penyesuaiannya harus ada kesepakatan bersama sehingga mempermudah pasangan suami istri dalam berkomunikasi dan meminimalis konflik yang di akibatkan oleh perbedaan budaya dan bahasa itu sendiri. Pasangan Indonesia - Italia melakukan cara berkomunikasinya dengan mengartikan orang benda di 
sekitar mereka kemudian makna atau simbol itu digunakan sebagai petunjuk agar masing- masing pasangan dapat mengerti dan tidak mengalami kesalahpahaman dalam menerima makna yang disampaikan. Kebiasaan komunikasi dengan cara yang khas terjadi dalam kehidupan sehari- hari sehingga proses yang terjadi lama lama menjadi sebuah simbol dari pasangan beda negara ini.

Komunikasi verbal dan nonverbal sebagai bentuk interaksi simbolik yang terjadi antar pasangan suami istri dari negara yang berbeda. Simbol verbal dan nonverbal yang sering digunakan pada pasangan Indonesia - Itali dengan menggunakan bahasa, gerak isyarat tangan dan jari, bahasa tubuh, ekspresi wajah dan kontak mata sebagai bentuk simbol dan petunjuk dalam berkomunikasi dengan makna yang telah di sepakati.

Dalam keluarga perkawinan campuran ada beberapa alternatif dalam upaya penyesuaian berkomunikasi yaitu:

1. Penyesuaian satu arah (one way adjustment); Salah satu mengadopsi pola budaya pasangannya. Pasangan Indonesia italia dan pasangan Indonesia - Jerman sepakat untuk mengadopsi budaya masing-masing pasangan sebagai bentuk penyesuaian yang mudah dalam rumah tangga seperti penyesuian bahasa dan cara berkomunikasi.

2. Penyesuaian alternatif (alternative adjustment); Pada satu kesempatan salah satu budaya diterapkan, tapi pada kesempatan lain pada budaya lainnya. Kedua pasangan beda negara seperti Indonesia - Italia dan Indonesia - Jerman menerapkan hal yang sama dimana sang suami ingin menerapkan hal berbeda dalam mendidik anak sebagai penyesuaian alternatif dengan menggunakan latar belakang budaya dari negara asalnya ataupun sebaliknya sang istri juga menerapkan budaya Indonesia di saat yang diperlukan karena mereka tinggal di Indonesia.

3. Kompromi midpoin (midpoint compromise); Kedua pihak sepakat untuk menentukan posisi masingmasing sebagai jalan keluar. Kedua pasangan ini juga telah sepakat dalam menentukan jenis komunikasi apa yang akan di pakai sebagai jalan keluar jika terjadi permasalahan dalam kelangsungan perkawinan.

4. Penyesuaian campuran (mixing adjustment); Kombinasi dari dua budaya yang sepakat untuk diadaptasi. Negara Indonesia dengan Italia, Indonesia dan Jerman sangatlah berbeda dalam segala hal seperti kebudayaan. Jika perkawinan campuran terjadi antar negara ini, pasangan suami istri mengkombinasi beberapa budaya dari masingmasing pasangan untuk mendapatkan kemudahan segala hal dalam penyesuaian perkawinan.

5. Penyesuaian kreatif (creative adjustment); Kedua pihak memutuskan untuk tidak mengadopsi budaya masing-masing tetapi mencari pola perilaku yang baru. Dengan mengadaptasi dan membuat beberapa bahasa dan lambang sebagai simbol baru dalam berkomunikasi adalah cara praktis sebagai alat komunikasi yang telah di sepakati antar kedua belah pihak.

\section{Kesimpulan}

Perkawinan campuran mengalami proses adaptasi dalam penyesuaian keseimbangan ketika berkomunikasi, 
seperti halnya komunikasi verbal dan nonverbal. Komunikasi verbal dan nonverbal adalah bentuk interaksi simbolik yang terjadi terhadap pasangan suami istri dari negara yang berbeda. Bahasa mix yang di ciptakan pada dasarnya digunakan atas kesepakatan bersama antara pasangan beda negara sehingga cara berkomunikasi khas tercipta seperti bahasa, gerak isyarat tangan dan jari, bahasa tubuh, ekspresi wajah dan kontak mata sebagai bentuk simbol dan petunjuk dalam berkomunikasi dengan makna yang telah di sepakati.

Upaya penyesuaian dalam berkomunikasi perlu dilakukan terhadap pasangan suami istri yang melakukan perkawinan campuran seperti dengan mengadopsi salah satu bentuk komunikasi pasangannya, menerapkan beberapa budaya komunikasi pada kesempatan yang berbeda, sepakat untuk menentukan komunikasi verbal dan nonverbal masing-masing sebagai cara komunikasi dan memutuskan untuk tidak mengadopsi budaya masingmasing tetapi mencari pola perilaku yang baru dalam berkomunikasi. Komunikasi adalah media yang dapat menciptakan atau mengatur suatu hubungan dalam berumah tangga dengan perbedaan budaya pada khususnya.

\section{Daftar Pustaka}

Agus M.Hardjana. 2003. Komunikasi Intrapersonal dan Interpersonal. Yogyakarta: Kanisius

Alo Liliweri. 2004. Dasar-dasar komunikasi antarbudaya. Yogyakarta: Pustaka Pelajar.

Budyatna M. \& Leila Mona G. 2011. Teori Komunikasi Antarpribadi. Jakarta: Kencana.
Deddy Mulyana. 2002. Ilmu Komunikasi Suatu Pengantar. Bandung: Remaja Rosadakarya.

Deddy Mulyana \& Jallaludin Rakhmat. 2009. Komunikasi AntarBudaya. Bandung: Remaja Rosadakarya.

Dodd, Carley H. 1998. Dynamics of Intercultural Communication (Fifth Edition). USA: The McGraw-Hill Companies, Inc.

Griffin. E.M. 2012. A First Look at Communication Theory (Eighth Edition). Amerika: McGraw Hill

Haryono P. 1993. Pemahaman Menuju Asimilasi Kultural. Jakarta: Pustaka Sinar Harapan.

Marhaeni Fajar. 2009. Ilmu Komunikasi Teori dan Praktek. Jakarta: Graha Ilmu

Moediarti Trisnaningsih. 2009. Beberapa Persoalan Dalam Hukum Perkawinan Di Indonesia. Garut: CV. Mardian Pratama. 